\title{
Black Genocide? Preliminary Thoughts on the Plight of America's Poor Black Men
}

\author{
By Robert Johnson and Paul Leighton
}

\author{
Journal of African American Men, v 1 \#2, Fall 1995 \\ Downloaded from http://paulsjusticepage.com > Class, Race, Gender \& Crime
}

\begin{abstract}
Our aim in this article is to offer an examination and preliminary defense of the claim heard frequently these days that poor African American men are subjected to conditions of life that are sufficiently destructive to amount to an instance of genocide. To make our case, we define the term genocide and apply measures of this phenomenon to the life experiences of poor black American men. Our focus is on grossly disproportionate death rates among this group, which we examine as one of a number of products of social deprivation. The emphasis is on understanding indirect genocide, which involves creating life conditions which destroy a group and facilitate black on black violence.
\end{abstract}

"Not since slavery," notes former U.S. Secretary of Human Services Dr. Louis Sullivan, "has so much calamity and ongoing catastrophe been visited on Black males" (Majors \& Gordon, 1994:ix). The calamities and catastrophes to which Dr. Sullivan alludes fall disproportionately on poor black males, especially the poor young black men who inhabit our nation's ghettos. This has led many observers to characterize poor black men as an endangered species (see Gibbs, 1988). Mortality data and other social indicators, discussed in this article, suggest that Dr. Sullivan's observation is fundamentally correct, particularly when it is applied to the plight of poor black men. The notion that these men comprise an endangered species is, however, a misleading and ultimately counterproductive one.' A more accurate view, though we can offer only tentative proof and argument at this juncture, is that such men may be victims of genocide. (We believe this claim holds for poor black women as well, but that takes us beyond the confines of this article.)

Those who identify poor black men as an endangered species do so out of concern, to raise an alarm and move society to compassionate action. The term is thus used with the best of intentions. Yet one can't help but note that the very notion of an endangered species of people is dehumanizing. Reference to any group or subgroup of people as a "species," let alone a species at risk, sets them apart, implicitly, as less than fully equal with other human beings. Such labels may inadvertently reinforce harmful stereotypes of poor black men, making it harder for outsiders to fully appreciate the scope of the pressures affecting their lives, pressures that we suggest may well reach genocidal proportions. 
As a general matter, people are strongly inclined to deny genocide wherever and whenever it occurs, and to do so firmly, and even passionately, when the group at issue can be readily dehumanized (see Chalk and Jonassohn, 1990:7). This is clearly the case with the black men in our inner cities. It is a bitter irony that, for many in the larger white society, they comprise not only different species of men but a distinctly predatory group that is largely if not entirely responsible for their impoverished, violent, and shortened lives. Few care to invest time or money in the preservation of this endangered species.

It is to be expected, then, that the subject of black genocide has not been assessed in objective or dispassionate terms. White scholars have essentially ignored the issue, viewing the claim as a type of lunacy. An earlier black scholar named Pattersor formally charged the United States with the genocide of blacks in the United Nations during the 1950s (see Patterson, 1970, 1971). Later black writers have tackled the issue (Weisbord, 1975; Welsing, 1974), but they have done so in a piecemeal fashion and have failed to ground their arguments in the intellectual tradition of genocide research.

There can be no doubt that many African Americans sincerely believe that the more marginal members of their community, if not indeed all black Americans, are actual or potential targets of genocide in America today. Some observers state these beliefs quite bluntly, decrying conspiratorial plans to annihilate the black race. The typical reaction to such accusations among white Americans, observed a Newsweek writer, is outright rejection of claims seen as nothing less than bizarre: "The ideological wagons are drawn into a circle with sensible mainstream American reason inside, threatened but valiant, and the crazy assault of black-American paranoia without" (Cary, 1992:23). A recent article in U S New \& World Report was entitled "The return of the paranoid style in American politics" (March 12, 1990:30). The aim of the article was revealed in the subtitle, which read in part, "why some blacks ... fear 'genocide."' We find it significant that the term "paranoid" was used literally (without quotations) while the term "genocide" was used figuratively (within quotes). The implication is that one must be crazy-and more specifically, paranoid-to think that some black Americans are victims of genocide. We contend that it is entirely possible that the paranoia alluded to is figurative and the feared genocide is literal.

The issue of black genocide should not be dismissed as "mumbo jumbo," as occurred in a prominent Time magazine essay (White, 1990:20). Poor black men are subjected to many disabling conditions that restrict opportunity, inflict pain and suffering, and shorten lives. It is of course true that black males are not slated for the death camp and institutionalized slaughter. Nevertheless, the evidence, though still incomplete, strongly suggests that the plight of poor African American males goes beyond simple political oppression and indeed crosses the threshold of genocide.

\section{DIMENSIONS OF GENOCIDE}

Ervin Staub. drawing on a wide-ranging study of the subject, defines genocide as "an attempt to exterminate a racial, ethnic, religious, cultural, or political group, either directly through murder or indirectly by creating conditions that lead to the group's destruction" (1989:8). Terms like "exterminate" harken back to the Holocaust and bring to mind Nazi death camps replete with ovens and gas chambers as settings of mass 
execution. But a careful reading of Staub's definition makes clear that the methods used to achieve genocide span direct violence (such as individual and mass murder) as well as indirect violence (primarily systematic deprivation).

The targets of genocide, Staub reminds us, are diverse and need only comprise a recognizable social group. Critically, the key concept at the core of the notion of genocide-destruction of a group—is not limited to physical violence. As Staub explains:

The essence of evil is the destruction of human beings. This includes not only killing but creation of conditions that materially or psychologically destroy or diminish people's dignity, happiness, and capacity to fulfill basic material needs. (Staub, 1989:25)

The notion that genocide need not entail physical violence is reinforced by Lemkin, who coined the term genocide-from the Greek work genos (race or tribe) and the Latin cide (kill)—and helped draft the United Nations Genocide Convention. At the heart of genocide, Lemkin writes, is "the destruction of the essential foundations of the life" of the group (see Kuper, 1985:9). This means that the systematic degradation of a group, with resulting psychological and material impoverishment, is an instance of genocide when it results in the widespread destruction of human lives. Thus, creating conditions in which a group will be destroyed, and not only direct violence against such a group, is a form of genocide.

The image many people have of genocide is limited to extreme and direct violence, perhaps best exemplified in the Nazi Holocaust. This image is misleading. The Nazi Holocaust represents the extreme or limiting case of genocide, not the paradigm, just as a rape-murder-disembowelment represents the extreme or limiting case of murder, not the paradigm of murder. The touchstone consideration in defining genocide is the destruction of the group. This means that mere discrimination or even oppression is not enough to qualify as genocide. Actions or conditions must threaten or undermine the very existence of the group in question.

Several instances of man-made famine have resulted in genocide. These famines are man-made in the sense that they were created or tolerated as a matter of policy. The indirect violence of policies that allow the ravages of famine "combines advantages-for the perpetrators - of costing very little while at the same time putting physical distance between them and the victims" (Jonassohn, 1992:23; see also Smith, 1987:35). If creating or tolerating a famine is genocidal, there is no reason, in principle, why it is not genocidal to create or tolerate multiple destructive life conditions-including high infant mortality, limited access to health care, crushing poverty, inadequate schools, and crime-racked neighborhoods that are also likely to contain toxic waste-all conditions that apply to the daily existence of poor black Americans (see, Reiman, 1995).2

An obvious case of indirect genocide occurs when the perpetrator creates a condition (such as famine) that destroys a group (through starvation) The Irish potato famine of the nine-teenth century comes readily to mind. Policies set in England resulted in shortages of food in Ireland; hunger, aided by diseases that run rampant in malnourished groups, terminated lives on a large scale Throughout, destructive policies were left in place, even as the dead accumulated (see Woodham-Smith, 1980; 
Rubenstein, 1987 2S7). With the creation of more amorphous conditions such as poverty, however, genocidal results may be achieved through self destructive adaptations to those conditions. The link between policy and outcome remains but is less obvious.

\section{BLACK ON BLACK CRIME}

In America, at least, poverty rarely kills directly. Few people drop dead in the streets from hunger or exposure to the elements. But poverty does produce a range of physical and psychological stresses, and some reactions to these stresses are expressed in behaviors that destroy life. We therefore suggest that destruction need not come only from outside the group. Members of the victim group may contribute to their own victimization through adaptations to bleak life conditions that include violence directed at self or others (e.g., suicide and homicide) as well as self-destructive lifestyles (notably addiction to drugs and alcohol). Williams, in his classic Destruction of Black Civilization, writes:

They, the so-called criminals and their youthful followers, expect nothing beneficial from the white world, and they see no reason for hope in their own. Hence, like caged animals, they strike at what is nearest them-their own people. They are actually trying to kill a situation they hate, unaware that even in this, they are serving the white man well. For the whites need not go all out for "genocide" schemes, for which they are often charged, when blacks are killing themselves off daily on such a large scale. (1987:325)

Adaptations that produce high rates of such destructive behavior, such as intra-group violence, suicide, and addiction, may thus serve as vehicles of genocide. Indirect genocide, then, can be expressed in part in the self-destructive adaptations of victim groups to the deprivations of life inflicted upon them by the larger society. In these situations, the victim group appears to be the cause of its own problems and the role of larger social conditions is discounted or ignored entirely. It is commonly said, for example, that poor black men are killing themselves with guns and drugs. Other sources of increased mortality in the black community, such as those related to poor physical health, can be dismissed on the same grounds. The culprit is their diet or lifestyle, not the pressures of poverty or racism. The notion that these choices may reflect adaptations to genocidal pressures is not given due consideration. The refrain, "they kill themselves," then, must be met with the rejoinder, "but society sets the stage for that violence."

Nevertheless, when victims of poverty victimize others in turn-as occurs most notably and most tragically in the case of black-on-black violent crime-victimizers remain culpable for their actions. Reiman makes this point quite clearly: "To point to the unique social pressures that lead the poor to prey on one another is to point to a mitigating, not an excusing, factor. Even the victims of exploitation and oppression have moral obligations not to harm those who do not exploit them or who share their oppression" (Reiman, 1995). Indeed, even the victims of the virtually unparalleled exploitation and 
oppression of the Nazi death camps held each other accountable to a moral code that prohibited abusing fellow sufferers (see Cohen, 1953; Des Pres, 1977).

To point to genocidal conditions as sources of self-destructive behavior among victim groups, then, is not to exonerate the offending individuals for their conduct. But though such individuals are responsible for the choices they make, we must realize that they make those choices within a broader social context marked, in Rubenstein's words, by a "socioeconomic predicament which is itself profoundly antisocial" (1987:206; see also Braithwaite, 1992). Violence and drug abuse are not overrepresented in our ghettos by chance, as though these settings of poverty were merely neutral staging grounds for destructive behavior. Ghettos, instead, are brutal and indeed profoundly antisocial environments that, through the pressures they offer, promote a host of destructive adaptations to daily life. These social forces offer mitigating conditions, reducing but not eliminating culpability for destructive individual adaptations.

Several powerful dynamics, some noted earlier, hinder us in seeing the situation clearly. The larger society is quite removed from the grim life circumstances and daily degradations experienced by poor blacks, and hence the average American has little real feeling for the forces that shape their lives. Much of the destruction of black life occurs in urban ghettos. Not unlike their counterparts in Nazi-occupied Europe, these ghettos are a no-man's land to people from the larger society. These environments are, in fact, the functional equivalent of prisons; people in these oppressive settings desperately want out, and those who make it out to better worlds desperately want to stay out. Few people visit ghettos willingly, unless they have relatives there; even fewer aspire to reside there if other choices are available. As a result, the indirect causal chain that ends with systematically high rates of mortality in these invisible ghettos can be hard for outsiders - the larger society - to appreciate. Here, death flows not from gas chambers and state-sponsored torture but from lives marked by deprivation and desperation.

The relative subtlety of this process, combining a hidden location and indirect dynamics, makes the causal chain less visible and helps explain the mystified reaction many have to the claim of black genocide. A further complication is that not all maladaptive behavior in the ghetto is the result of genocidal pressures. Not every mishap that befalls a black American is the fruit of poverty or racism. These days, the claim that one is a victim can be empowering, giving one more rights and fewer responsibilities. In the presence of a cult of victimization, where everyone seems to have an excuse for his or her misconduct, all claims of victimization are rendered suspect these days. Some of this suspicion is no doubt justified, but there is a real danger that one will too readily reject the claims of legitimate victims.

One must move cautiously here. There is a sense in which victim claims have always been met with skepticism, independent of their merits. The very notion that life is profoundly unjust and that the world is populated with untold numbers of innocent victims is deeply foreign to human nature (Ryan, 1971). Most people-and perhaps at some level, all people-subscribe to what has been termed a "just world ideology." Central to this ideology is the belief that bad things simply do not happen to good people. If life treats you well, you are a good and deserving person. If life treats you badly, you must be a bad person or at least someone who is undeserving of a good life.

Johnson \& Leighton, Black Genocide p 5 of 18.

Downloaded from http://paulsjusticepage.com > Class, Race, Gender \& Crime 
Children in the ghetto routinely assume that life for them is hard because they are bad people. To be sure, these children are encouraged to display Black Pride, to celebrate Black History Month, and to believe that Black is Beautiful. But for many, this is empty ritual. In their daily lives, many and perhaps most of these ghetto children work on the explicit assumption that black is bad. The mere appearance of black children in stories is interpreted by some ghetto children to spell trouble and despair (Elrich, 1994).

Following a story in which a young black boy who had tried to steal a woman's purse is redeemed by her forgiveness and love, a black "A" student in a class filled with poor minority children raised his hand and said, "You knew something bad was going to happen when it started. As soon as you see a black boy you know he's gonna do something bad." The teacher, a white male, was taken aback He asked, "Just because he's black, he's bad?" The student replied, unfazed: "Everybody knows that black people are bad. That's the way we are." Eirich polled his class and discovered a "near consensus" among these children that blacks are stupid, lazy, violent, shiftless and irresponsible, and are born to be bad. Whites, the children claimed, are the opposite. Elrich concluded that these children's hopes and dreams are killed off by a "stereotype within" that is a strong and pervasive legacy of racism and poverty.

The appeal of the just world ideology is that it offers an image of a rational and responsive world in which one gets what one deserves, whether good or bad. The downside of the just world ideology is that recognition of injustice is difficult because it threatens one's orderly view of life. "According to this principle, people are strongly motivated to maintain the belief that the world operates according to just principles, 'for the sake of maintaining their own sanity,' even if it means that one must reject a suffering victim" (Calhoun and Townsley, 1991:61). When bad things happen to good people, we are tempted to ignore it, minimize it, or change our evaluation of the victim so the suffering seems deserved.

Often, we blame the victim for the harms that befall them. Walster, for example, studied attributions of responsibility for a car accident. He found that as the severity of the consequences increased, subjects assigned more blame to the victim. "Without making such attributions, people would have greater fear that such an event might happen to them" (Walster, 1966:75). The implication is that we blame the victim not solely out of malice, ignorance, and racism - though each of these ugly sentiments may be implicated-but for our own psychological protection. It is deeply reassuring to blame victims for their plight. If victims get what they deserve, then so will we. If we behave well, the logic runs, we will be treated well in turn. (Among the victims themselves, as we have seen, there are parallel pressures to blame oneself, on the premise that only bad people are treated badly in this world. The appeal of self-blame is that, at least in principle, one can decide to become good and then reap the benefits of a just world.)

The notion that some groups are victims of genocide is, then, almost literally unbelievable to those outside those groups and even difficult to believe for many members of the victim group itself. Great efforts are made to deny the atrocity that is genocide because to acknowledge genocide is to acknowledge a gross injustice that might envelop us all, cutting off hope for a safe and decent life. Note that many people denied the Holocaust when it occurred; certainly many European Jews denied the Holocaust even when it was unfolding, which made them more vulnerable to this terrible assault (see, Lifton \& Markusen, 1990). It took decades before the world was ready to 
address this troubling matter. And to this very day, in the face of voluminous documentary evidence, some people still maintain that the Holocaust was a hoax. Indirect genocide, which is by its nature difficult to appreciate, can be readily dismissed out of hand. "They are killing themselves," people say with varying degrees of smugness. And if something more is happening, it must be a mistake, an accident for which no one is to blame-other than, perhaps, the victims themselves.

\section{INTENT AND CULPABILITY}

Our view is that indirect genocide not only exists but is behavior for which people are fully culpable. Stated bluntly, those groups whose policies promote or permit the degradation and destruction of life are perpetrators of genocide. This is the case even if some or even many members of these groups merely stand and watch as the violence unfolds or indeed refuse to acknowledge the violence. And it is the case even if much of the destruction of the victim group is the result of maladaptive behavior on the part of the victims themselves. Since the destruction of the group from without or within is foreseeable, either at the outset or as the process of destruction unfolds, this violence is preventable and hence is behavior for which people can be held culpable.

An objection at this point is that foreseeing is not the same as intending. Even if conditions for poor black men create extreme misery and sharply foreshortened lives, we in the larger society do not intend or want those conditions to exist or to exert genocidal influences. Few Americans explicitly condone racism, and fewer still could be said to "desire" the extermination of blacks. We would agree, further, that there is little credible evidence to suggest the existence of an overt "plot" or a "conspiracy" to destroy African Americans.

But the notion of intent can encompass a wide variety of meanings. One sense of the term suggests an awareness for which one is culpable because one fails to act to prevent harms that, though not intended, can be foreseen as the outcome of one's actions. This is a case of indirect or oblique intention (Hare, 1990). To be sure, those who foresee and 'ail to act are less culpable than those who plan and carry out a harmful act and hence directly intend to harm others. However once harmful consequences occur with some regularity, unintended though they may have been at the outset, they then become matters of fact, not prediction. If known consequences are not acted upon, indirect intent is made direct. "[T]o persist" with destructive policies, whatever their original aim, "is to intend the death of a people" (Smith, 1987:23). In such instances one "lives out a relation of genocide" even if genocide is not ^ $\mathrm{o'}^{\prime}$ mdi'y or even explicitly intended by the dominant group (see Barta. 1987:239).

Direct and unambiguous genocidal intent can be inferred when the government has established concentration camps and a well-oiled machinery of death. In general genocidal states support a stronger Inference of intentionally than genocidal societies. But societies can be genocidal when their governments are not. There are societies "in which the whole bureaucratic apparatus might officially be directed to protect innocent people, but in which a whole race is nevertheless subject to remorseless pressures of destruction inherent in the very nature of society" (Barta, 1987:240). The colonization of Australia, examined by Barta (1987), fits this prescription. Rubenstein (1987) extends 
this analysis to other examples of European colonization, including the settlement of America with its concomitant relations of genocide between the colonists and Native Americans. Relations of genocide between whites and African slaves-and later, free African Americans-would seem to be of a piece with these experiences.

\section{DEATH RATES AND BODY COUNTS}

Genocide is typically measured in the grim statistics of the body count. In the Nazi Holocaust, executions occurred en masse. The dead fell in groups and were tallied in the millions. One can readily envision a vast field of the Holocaust dead, punctuated with countless mass graves, each filled with the bodies of men, women, and children, even infants. The effect is chilling.

No such body count comes readily to mind when discussing black genocide, yet such a body count can be established. After all, body counts encompass what amount to premature deaths, and the experiences of poor black American men have producedand continue to produce-a grim harvest of early death.

We all die. The key considerations are how and when. In the Nazi Holocaust, millions came to premature end's, most from outright murder, but many others from indirect murder due to intolerable life conditions in the European ghettos and concentration camps. Some, no doubt, died at the hands of fellow sufferers, who would, for example, steal food from their starving neighbors. Though little is written about this, it is certainly the case that antisocial and even criminal acts occurred within the concentration camps and ghettos, adding to the miseries wrought by the German authorities bent on genocide (see Cohen, 1953; Des Pros, 1977).

Statistics are available that allow us to estimate how many black Americans experience a reduced life expectancy relative to white Americans and hence come to premature ends. These premature deaths can be traced to oppressive life circumstances and to the adaptations of many black Americans to these conditions. Since these conditions are known and yet allowed to persist, these deaths, we contend, can be seen as the product of genocide in the form of indirect murders perpetrated or tolerated-at a minimum, sanctioned-by the larger society. Each premature death yields a body that is, figuratively speaking, interred in a mass grave fed by a flowing stream of genocide.

The figures on premature deaths are reported in table 1 . The data used to generate these statistics came from the 1991 Mortality Detail data set, which is produced by the Centers for Disease Control and Prevention.3 Our primary interest is in inner-city poor black men, sometimes referred to as a core segment of an American underclass, since they are most obviously threatened by depriving social conditions. The data available did not allow us to select out only this group, however, because death certificates do not include information on socioeconomic class. Also, as of this writing, we have not been able to obtain age-specific population figures for urban or metropolitan areas that correspond with data recorded on death certificates. As a result, our figures encompass privileged as well as under-privileged black Americans and hence underestimate, 
perhaps significantly, the incidence of premature deaths experienced by poor black Americans.

To reflect the notion of premature or untimely death, we calculated a life expectancy for men that was the average of the numbers of years lived for black and white males. In 1990, the last year for which life expectancy figures were available, African American males lived 64.5 years, and white males lived 72.7 years (Stat-Abs, 1993, Table 115, p. 85). The (unweighted) average is 68.6 years, so our computations stopped with the fiveyear age category 65-69. On an intuitive level, it may seem that because the life expectancy for black men is 64.5 , this is the age at which death stops being premature for black men. But the procedure we are following asks what would happen if blacks had the white death rate. If blacks had the (lower) death rate of whites, their life expectancy would increase. Likewise, whites would have a lower life expectancy if they had the higher death rate of blacks. Because of differences between these groups (for example, blacks and whites have different age distributions), we cannot necessarily assume that whites and blacks would simply switch life expectancy values it is safe to assert that the black life expectancy would increase while whites would expect to live fewer years. Thus, we decided simply to average the life expectancies of each group and then terminate the analysis of premature deaths in the age category that contained the appropriate average life expectancy.

Our overall method suggests that if whites and blacks experienced mortality rates that were roughly equal, the excesses from some causes and/or age categories would balance out deficits in others. The summation would thus produce a small number or one that should be zero. This is not the pattern we found. Indeed, the strength and consistency of the results make an interpretation of randomness untenable. Race is consistently and significantly related to increased risk of premature death. We suggest that, at the very least, the minimal levels of intentionality discussed above are satisfied. Our results do not indicate the causes of the discrepancy or the relative contribution of various causes, but the consistency and magnitude of the findings strongly suggest that blacks and whites in America are living out a relationship of genocide. 4

The best interpretation of the magnitude of the observed minus expected category is that it answers the question, How different would we expect the number of premature deaths to be if each race had the death rate of the other? If black men had the same death rate as white men, we would expect some 45,693 fewer black men to die prematurely each year. If white men had the death rate of black men, we would expect 376,992 more premature deaths each year. Some context helps us to further evaluate the significance of these numbers. In 1991, 95,064 black men died before age 69 . Based on the death rates of their white counterparts, we would have expected only 49,371 deaths. 


\begin{tabular}{|c|c|c|c|c|c|c|}
\hline & $\begin{array}{l}\text { Observed } \\
\text { Black Death }\end{array}$ & $\begin{array}{l}\text { Expected } \\
\text { Black } \\
\text { Death }\end{array}$ & $\begin{array}{l}\text { OBS-EXP } \\
\text { (BLACK } \\
\text { EXCESS) }\end{array}$ & $\begin{array}{l}\text { Observed } \\
\text { White } \\
\text { Death }\end{array}$ & $\begin{array}{l}\text { Expected } \\
\text { White } \\
\text { Death }\end{array}$ & $\begin{array}{l}\text { OBS-EXP } \\
\text { (White } \\
\text { Deficit) }\end{array}$ \\
\hline Cancer & 18,175 & 11,427 & 6,748 & 108,859 & 174,652 & 65,793 \\
\hline $\begin{array}{l}\text { Heart } \\
\text { Disease }\end{array}$ & 24,323 & 13,577 & 10,746 & 127,994 & 228,572 & 100,578 \\
\hline Homicide & 10,430 & 1,791 & 8,639 & 9,253 & 67,592 & 58,339 \\
\hline $\begin{array}{l}\text { Accident \& } \\
\text { Suicide }\end{array}$ & 13,945 & 10,062 & 3,883 & 70,435 & 100,861 & 30,426 \\
\hline $\begin{array}{l}\text { Pregnancy } \\
\text { \& Birth } \\
\text { Related }\end{array}$ & 4,882 & 2,302 & 2,580 & 10,565 & 22,682 & 12,117 \\
\hline $\begin{array}{l}\text { Diseases of } \\
\text { Body } \\
\text { Systems }\end{array}$ & 11,238 & 5,692 & 5,546 & 50,107 & 97,653 & 47,546 \\
\hline Other & 12,071 & 4,520 & 7,551 & 33,662 & 95,855 & 62,193 \\
\hline TOTAL & 95,064 & 49,371 & 45,693 & 410,875 & 787,867 & 376,992 \\
\hline \multicolumn{7}{|c|}{$\begin{array}{l}\text { The table indicates that if black men had the white death rate, they would have experienced } 45,693 \\
\text { fewer deaths in } 1991 \text {. If white men had the death rate of black men, an additional } 376,992 \text { white } \\
\text { men would have died in } 1991 .\end{array}$} \\
\hline \multicolumn{7}{|c|}{$\begin{array}{l}\text { NOTE: The expected numbers have been adjusted by } 5 \% \text { to help correct for the census } \\
\text { undercount of black men; the OBS-EXP also reflect this correction. }\end{array}$} \\
\hline
\end{tabular}

Some premature deaths are to be expected for any group. Under our procedure, we can determine that almost half of all premature black deaths can be described as being excess deaths in relation to their white counterparts. Conversely, we would expect some 787,867 white male deaths, though the observed number is 410,375 .

Homicide, which in our data includes the subcategory "legal interventions" (such as police shootings and executions), is the fourth-largest of the seven categories. Our analysis suggests that the great majority-80 percent-of the African American deaths in this category are excess deaths. Rather than the 10,430 black men represented in this category, we would expect only 1,791 given the white male death rate. (Examining only men aged 15 to 34 , a separate analysis reveals that there are 7,461 homicides rather than 1,017 deaths predicted from the white rate-and this after a 20 percent 
adjustment to correct for the greater census undercount of young black men relative to other demographic groups.) To give perspective beyond our present 1991 data set, note that as far back as 1981, the lifetime probability of a white woman's being a murder victim was 1 in 450, while for a black man the risk was 1 in 28 (Rosenberg, 1988:149). Here gender and race intersect to produce profound differences in longevity.

Conversely, our procedure suggests that if whites had the black homicide rate, we would expect a body count of almost 80,000 instead of the 12,000 observed in the 1991 statistics. The 9,253 white men killed by homicide would become 67,592 , a phenomenal figure by any reckoning. There would be an extra 32,000 deaths in the 15-to-34-yearold age bracket alone.) These substantial figures apply to one year only. Projected over decades, the result would be a body count of sizeable proportions. Under such circumstances, we doubt that the draconian crime bill recently passed by Congress, which allocates some $\$ 30$ billion on more police, more prisons, and more executions, would see the light of day. Prevention programs, which hold out the prospect of saving (white) lives rather than merely punishing devalued deviants, would almost certainly be given a higher priority.

The essential consideration in defining genocide is the destruction of the group. Thus, it is appropriate to compare the excess deaths suffered by blacks to the total black population. In this case, the total number of excess black deaths in 1991 was 78,951 and the total black population was 31.2 million. Of course, the almost 80,000 deaths are not a one-time setback but the accumulation of bodies from one year. Projected over decades, the excess deaths among black Americans reaches dramatic proportions. In the three decades since the emergence of the civil rights movement, excess or extra premature deaths among blacks total over two million (78,951 times 30 $=2,368,530$ ). Had whites experienced the death rates of blacks projected over these three decades, the result would be nearly twenty million extra premature deaths $(647,575$ deaths in the observed-expected category times 30 years $=19,427,250)$. Both figures are substantial, though the absolute number of whites who would die prematurely if they had the black death rate is breathtaking. There is no doubt that this body count would stun white America and spawn massive efforts to protect and preserve life.

Our data indicate that, in the vast majority of cases, the suffering of blacks is grossly disproportionate to their percent-age in the population Nevertheless, the majority of people who experience life-threatening conditions such as cancer, AIDS, and poverty are white Thus, some may argue that these statistics and the suffering they represent, though regrettable, are not evidence of genocide. However, the black death rate has considerably greater implications for the survival of the group than does the white death rate Remember that the key element of genocide is that it threatens the physical survival or integrity of a group. Blacks are a relatively small minority, comprising roughly 12 percent of our population The life-shortening conditions they experience amount to a threat of great magnitude, a threat that would be hard to imagine in the case of white Americans. Take, for example, the extreme hypothetical case of a government that 
summarily executed three blacks and seven whites each day. At that rate, the black population would be eliminated long before there was even a threat to the survival of white people. In other words, blacks would have been victims of genocide while whites would not, even though, absolutely speaking, whites would have experienced greater losses and more suffering.

In light of these considerations, it is at first blush something of a paradox that census estimates indicate that the African American population is stable and even growing slightly. The reason: a birth rate among black American women that is almost one-third higher than among white American women (see Black Children in America: 1993). Our point is that this population growth occurs in spite of-not because of-favorable and egalitarian conditions. Indeed, many of these excess births involve children born into lives of poverty and deprivation, which is to say, lives that may well be lived under conditions that are genocidal. That many children are born into the same environments that brutalized their parents is not a rebuttal of a presumption of genocide, since the same destructive forces will now simply operate on this slightly larger group, producing yet more of what has been aptly termed "angry aggression among the 'truly disadvantaged"' (Bernard, 1990:73). Moreover, marginal increases in what amounts to a surplus population neither improve the conditions of this group nor insulate the group from the destructive forces around them.

Given the high number of excess black deaths at the adult end of the spectrum, moreover, government-sponsored efforts to limit black births through various forms of birth control, though unsuccessful, may take on a new salience. Section (d) of the UN Genocide Convention discusses "imposing measures intended to prevent births within the group" (see Kuper, 1985).

Such measures are not always genocidal in intent or effect, but they are viewed with suspicion in many segments of the black community (see, Weisbord, 1975:94). To the extent that government-imposed birth control measures were to reduce the black birth rate to that of the white rate, one effect, intended or not, would be a steadily declining black population, since excess births would no longer compensate for excess deaths.

We have every indication that 1991 , the year for which our data were collected, is a typical year. The Statistical Abstract of the United States predicts that the relative life expectancies of black men and white men will not change substantially for those born through the year 2010; nor does the absolute number of years of projected life expectancy change dramatically for either of these groups (Table 115, p. 85) Some changes are anticipated, however, and these entail a relative worsening of the situation for black men relative to their white counterparts. 5

Surely these statistics amount to a prediction of continued high rates of excess premature deaths for black Americans, totaling roughly three-quarters of a million excess black dead per decade. Since this result is now known, we are obligated to act.

The failure to act to stem premature black deaths amounts to an intention to allow these deaths to occur, if not a desire for such deaths. The statistics on reduced life 
expectancy for black Americans, though sobering, tell only a portion of the story. The grave-yard of ruined black lives runs broader and deeper than a count of the prematurely interred. The living may experience a kind of death if violence is done to body or mind, affecting the individual by limiting his or her capacity for full human experience, sometimes captured in the notion of personhood. Hence, to the body count produced by shortened life span must be added a tally of various indices of the impairment or destruction of personhood experienced by members of a group. Each such impairment is a kind of violence. (The word violence derives from Latin violare, to violate.) Limitations of space prevent our discussion of these matters. The various violations of personhood and culture, meted out daily in a racist society, that consign so many black Americans to the violence of poverty need to be examined as an aspect of genocide, and we are presently engaged in such an endeavor.

\section{CONCLUDING THOUGHTS}

Black Americans by and large picture themselves as profoundly marginal and expendable to their white neighbors, leaving them with a sense of alienation. This alienation is perhaps best captured in the Chronicle of the Space Traders (Bell, 1990). In this story, blacks as a group are sacrificed to aliens for gold to retire the national debt, a chemical to clean up pollution, and a limitless source of clean energy. Following a national referendum and a Supreme Court decision, blacks are lined up and turned over to the aliens. The moral of this story is that we have made no racial progress; whites would sacrifice blacks for their own gain now just as they did 400 years ago with the institution of slavery. The Space Trader saga, however strained and extreme it may appear to whites, rings true to many blacks.

Among blacks, the chronicle "captures an uneasy intuition" that black Americans "live at the sufferance of whites-that as soon as our [black] welfare conflicts with something they [whites] consider essential, all our gains, all our progress, will turn out to be illusory" (Delgado and Stefancic 1991:321).

From the vantage point of poor blacks, the much-touted racial progress that is believed to have occurred in America since the civil rights movement is a cruel myth. For many of today's ghetto dwellers, things are worse, much worse, than was the case when Martin Luther King announced his dream of a color-blind America. Kozol's work in ghetto schools offers compelling testimony on this observation: All that stuff about "the dream" means nothing to the kids I know in East St Louis. So far as they're concerned, he died in vain. He was famous and he lived and gave his speeches and he died and now he's gone. But we're still here. Don't tell students in this school about "the dream." Go and look into a toilet here if you would like to know what life is like for students in this city. (Kozol, 1991:36)

Just as the reservation has become the locus for an invisible and expendable population of Native Americans-a setting marked by social marginality, blocked opportunity, suffocation of initiative and autonomy - so has the ghetto become a kind of island of abandoned black people. In the case of blacks, at least, these isolated urban islands are surrounded by a sea of white racism. 
The vulnerability many African Americans feel, expressed so compellingly in the Space Trader scenario, must be taken seriously. The relevant question for them has been posed by Rubenstein: "At the very least, one must ask whether the bonds of community between Americans would be sufficiently strong to protect the poor in a crisis?" (1987:213). When this question is amended to focus on the black poor, the answer many would give is, quite bluntly, a resounding "No "

\section{REFERENCES}

Anderson, S. E., The Black Holocause: For Beginners New York: Writers and Readers, Inc, 1995

Aronowitz, Stanley and William DiFazio. The Jobless Future: Sci-Tech and the Dogma of Work. Minneapolis: University of minnesota Press, 1994.

Austin, Regina and Michael Schill. "Black, Brown, Poor \& Poisoned: Minority Grassroots Environmentalism and the Quest for Eco-Justice" The Kansas Journal of Law and Public Policy Summer 1991, 69.

Barta, T., "Relations of Genocide: Land and Lives in the Colonization of Australia." In Walliman, Isidor and Michael Dobkowski (eds). Genocide and the Modern Age: Etiology and Case Studies of Mass Death. New York: Greenwood Press, 1987.

Bell, Derrick. "Chronicle of the Space Traders" Rutgers Law Review v 42 (1990) p 1; revised and expanded version in St. Louis Law Review v 34 (1990) p 3.

Black Children in America: 1993, Bureau of the Census: Statistical Brief for Congress. CB/94-1:September 1994.

Braithwait, John. "Poverty, Power and White-Collar Crime" in Schlegel, Kip and David Weisbord (eds) White Collar Crime Reconsidered. Boston: Northeastern University Press, 1992.

Brown, DeNeen, "Getting Ready to Die: Children in Violent D.C. Neighborhoods Plan Their Own Funerals," The Washington Post, Monday, November 1, 1993:A1 \& A8.

Brown, Robert McAfee. Religion and Violence, 2nd ed. Philadelphia: The Westminster Press, 1987.

Bullard, Robert. Dumping in Dixie: Race, Class and Environmental Quality. Boulder: Westview, 1990.

(ed.). Unequal Protection: Environmental Justice and Communities of Color. San Francisco: Sierra Club Books, 1994. 
Bureau of Justice Statistics. Prisoners in 1994. August, 1995; NCJ-151654.

Calhoun, Karen and Ruth Townsley "Attributions of Responsibility for Acquaintance Rape" in Andrea Parrot and Laurie Bechhofer (eds) Acquaintance Rape: The Hidden Crime

Cary, Lorene. "Why It's Not Just Paranoia" Newsweek April 2, 1992, p 23.

Chalk, Frank and Kurt Jonassohn. The History and Sociology of Genocide. New Haven: Yale University Press, 1990.

Christie, Nils. Crime Control As Industry: Toward Gulags, Western Style? London: Routledge, 1993.

Cohen, E. A., Human Behavior in the Concentration Camp. New York: Norton, 1953.

Delgado, Richard and Jean Stefancic. "Derrick Bell's Chronicle of the Space Traders: Would the U.S. Sacrifice People of Color if the Price Were Right?" University of Colorado Law Review v 62 (1991) p 321.

Des Pres, T., The Survivor: An Anatomy of Life in the Death Camps. New York: Pocket Books, 1977.

Doyle, James. "It's The Third World Down There!': The Colonialist Vocation and American Criminal Justice" Harvard Civil Rights-Civil Liberties Law Review. v 27, 1992, p 71.

Elrich, M., "The Stereotype Within: Why My Students Don't Buy Black History Month," The Washington Post, Outlook Section, Sunday, February 13, 1994:C1 \& C4.

Essed, P., Everyday Racism: Reports from Women in Two Cultures. Claremont, CA: Hunter House, 1990.

Understanding Everyday Racism: An Interdisciplinary Theory. Newbury, CA: Sage, 1991.

Fletcher, M. A., "Conspiracy theories can often ring true: History feeds blacks' mistrust," The Washington Post October 4, Friday, 1996: A1 \& A18).

Garwood, Alfred (ed). Black Americans: A Statistical Sourcebook (1993 ed). Boulder: Numbers and Concepts, 1993).

Gordon, Diana. The Justice Juggernut: Fighting Crime, Controlling Citizens. New Brunswick: Rutgers University Press, 1990.

Hacker, Two Nations: Black and White, Separate, Hostile, Unequal. New York: Ballantine, 1995. 
Hare, R.M. "Public Policy in a Pluralist Society" in Peter Singer, Helga Kuhse, et al (eds). Embryo Experimentation. Cambridge: Cambridge University Press, 1990.

Harvard Law Review. "Developments in the Law: Race and the Criminal Process" Harvard Law Review. v 101, 1988, p 1472.

Horowitz, Irving Louis. Taking Lives: Genocide and State Power. New Brunswick: Transaction Books, 1980.

Jonassohn, Kurt "What Is Genocide?" in Fain, Helen (ed). Genocide Watch. New Haven: Yale University Press, 1992.

Jones, James H. "The Tuskegee Legacy: AIDS and the Black Community" The Hastings Center Report v 22, Nov/Dec 1992, p 38-40.

Bad Blood: The Tuskegee Syphilis Experiment. New York: The Free Press, 1993.

Kozol, Johnathan. Savage Inequalities: Children in America's Schools. New York: HarperCollins, 1991.

Kuper, Leo. The Prevention of Genocide. New Haven: Yale University Press, 1985.

Kunjufu, Jawanza. Countering the Conspiracy to Destroy Black Boys. Chicago: African American Images, 1985

Lee, Charles "Toxic Waste and Race in the United States" in Bunyan Bryant and Paul Mohai (eds) Race and the Incidence of Environmental Hazards: A Time for Discourse. Boulder: Westview Press, 1992.

Lerner, M.J. and C.H. Simmons. "Observer's reaction to the 'innocent victim': Compassion or Rejection?" Journal of Personality and Social Psychology v 4 (1966) 203-210.

Lusane, Clarence. Pipe Dream Blues: Racism and the War on Drugs. Boston: South End Press, 1991.

Majors, Richard and Jacob Gordon (eds). The American Black Male: His Present Status and His Future. Chicago: Nelson:-Hall, 1994.

Mandell, J. R., The Roots of Black Poverty: The Southern Plantation Economy After the Civil War (Durham: Duke University Press) 1978.

Marable, Manning. How Capitalism Underdeveloped Black America:Problems in Race, Political Economy and Society. Boston: South End Press, 1983.

Massey, Douglas and Nancy Denton. American Apartheid: Segregation and the Making 
of the Underclass. Cambridge, MAss.: Harvard University Press, 1993.

Mauer, Marc. "Americans Behind Bars-- A Comparison of International Rates of Incarceration" in Ward Churchill and J.J. Vander Wall (eds). Cages of Steel: The Politics of Imprisonment in the United States. Washington, DC: Maisonneuve Press, 1992.

Young Black Men and the Criminal Justice System: Five Years Later. Washington, D.C.: The Sentencing Project, 1995.

Miller, Jerome. Search and Destroy: African American Males in the Criminal Justice System. Cambridge: Cambridge University Press, 1996.

National Center on Institutions and Alternatives. Hobbling A Generation: Young African American Males in Washington, DC's Criminal Justice System. Alexandria, VA: National Center on Institutions and Alternatives, April 1992.

Oshinsky, D. M., Worse than Slavery: Parchman Farm and the Ordeal of Jim Crow Justice. New York: Free Press, 1996.

Patterson, William (ed). We Charge Genocide: The Crime of Government Against the Negro People. New York: International Publishers, 1970 (reprint of 1951 edition published by Civil Rights Congress).

The Man Who Charged Genocide: An Autobiography. New York: International Publishers, 1971.

Pinkney, Alfonso. The Myth of Racial Progress. Cambridge: Cambridge University Press, 1984.

Reiman, Jeffrey. The Rich Get Richer and the Poor Get Prison: Ideology, Class and Criminal Justice, 4th ed. New York: Macmillan, 1994.

Rifkin, Jeremy. The End of Work. New York: G.P. Putnam's Sons, 1995

Rosenberg, Mark I. "Violence Is A Public Health Problem" in Russell Maulitz (ed) Unnatural Causes: The Three Leading Killer Diseases in America. New Brunswick: Rutgers University Press, 1988.

Rubenstein, R. L., "Afterword: Genocide and Civilization." In Walliman, Isidor and Michael Dobkowski (eds). Genocide and the Modern Age: Etiology and Case Studies of Mass Death. New York: Greenwood Press, 1987.

Ryan, William. Blaming the Victim. New York: Random House, 1971.

Sampson, R. J. \& Wilson, W. J., "Toward a theory of race, crime, and urban inequality," in Hagan, J. \& Peterson, R. D. (Eds), Crime and Inequality (Stanford: Stanford University Press) 1995:37-54. 
Shammas, Carole. "A New Look at Long-Term Trends in Wealth Inequality in the United States" American Historical Review v 98 \#2, April 1993, p 412.

Smith, Roger "Human Destructiveness and politics: The Twentieth Century as an Age of Genocide" in Walliman, Isidor and Michael Dobkowski (eds). Genocide and the Modern Age: Etiology and Case Studies of Mass Death. New York: Greenwood Press, 1987.

Stampp, K. M., The Peculiar Institution: Slavery in the Ante-Bellum South (New York: Vintage Books) 1956.

Staub, Ervin. The Roots of Evil: The Origins of Genocide and Other Group Violence. New York: Cambridge U. Press, 1989.

Swinton, David. "The Economic Status of African Americans During the Reagan-Bush Era: Withered Opportunities, Limited Outcomes, and Uncertain Outlook" in The State of Black America, 1993. New York: National Urban League, 1993.

Weisbord, Robert. Genocide? Birth Control and Black America. (Published jointly) Westport: Greenwood Press, and New York: Two Continents Publishing Group Ltd., 1975.

Welsing, Frances Cress. "The Cress Theory of Color Confrontation" Black Scholar. May 1974, p 32.

The Isis (Ysis) Papers. Chicago: Third World Press,

West, Kirsten and David Fein. "Census Undercount" Sociological Inquiry v 60, Spring 1990:126.

White, Jack. "Genocide Mumbo Jumbo" Time January 22, 1990, p 20.

Willhelm, Sidney. Who Needs The Negro? Cambridge: Schenkman Publishing, 1970.

Williams, Chancellor. The Destruction of Black Civilization. Chicago: Third World Press, 1987.

Wilson, W. J., The Truly Disadvantaged: The Inner City, the Underclass, and Public Policy (Chicago: Chicago University Press) 1987.

When Work Disappears: The World of the New Urban Poor. New York: Knopf, 1996.

Wolter, Kirk. "Accounting for America's Uncounted and Miscounted" Science v 253, 5 July 1991:12.

Woodham-Smith, C., The Great Hunger: Ireland, 1845-1849. New York: E.P. Dutton, 1980. 